STANISEAWA NAZARUK

Państwowa Szkoła Wyższa im. Papieża Jana Pawła II

$w$ Białej Podlaskiej

ANNA KLIM-KLIMASZEWSKA

Uniwersytet Przyrodniczo-Humanistyczny

$w$ Siedlcach

\title{
EDUKACJA WIELOKULTUROWA SZANSĄ NA INTEGROWANIE UCHODŹCÓW ZE SPOŁECZNOŚCIĄ LOKALNĄ
}

\begin{abstract}
Nazaruk Stanisława, Klim-Klimaszewska Anna, Edukacja wielokulturowa szansa na integrowanie uchodźców ze społecznością lokalną [Multicultural Education as a Chance for the Integration of Refugees Into the Local Community]. Studia Edukacyjne nr 43, 2017, Poznań 2017, pp. 153-164. Adam Mickiewicz University Press. ISSN 1233-6688. DOI: 10.14746/se.2017.43.9

Currently we are witnessing migration, which for different reasons exhibits a growth tendency. It does not just concern big cities, but also smaller towns, where we can encounter people with different cultural backgrounds, religion, dialect, and values. Multicultural education comes out to meet the expectations of the minorities and its main purpose is to create a platform for dialog and communication, as well as the composition of educational programs and multicultural upbringing. The article explains the situation of refugees, with emphasis on the education and upbringing of children. It provided examples of multicultural education implemented in a small elementary school from a County of Bielsk.
\end{abstract}

Key words: multicultural education, intercultural education, refugee, integration

Współcześnie w coraz większym stopniu obserwowane jest zjawisko migracji. Prognozy wykazują jego systematyczną tendencję wzrostową. Nawet $\mathrm{w}$ małych społecznościach mieszkają obok siebie ludzie różniący się m.in. kulturą, religią, dialektem i wartościami. Zbiorowości, w których znajdują się mniejszości podejmują działania asymilacyjne, izolacyjne lub tworzą płaszczyznę porozumienia i dialogu opartą na wiedzy, wzajemnym zrozumieniu, kooperacji i pluralizmie. Z konieczności skrótowo zarysowane zja- 
wisko stanowi poważne wyzwanie natury pedagogicznej, z uwagi na wspó1życie obok siebie przedstawicieli różnych kultur, co wymaga podjęcia działań, które stworzą płaszczyzny porozumienia między odrębnymi ,,żywiołami".

\section{Geneza i przykłady edukacji wielokulturowej}

Początki edukacji wielokulturowej wiążą się z obecnością w szkołach dzieci imigrantów. Spowodowało to liczne pytania o treści nauczania, cele, formy, metody kształcenia i wychowania, a w efekcie wprowadzania nowych programów nauczania o treściach ujmujących różnorodność rasową, religijną i kulturową społeczeństw.

W USA koncepcja wielokulturowej oświaty funkcjonowała już w pierwszych dekadach XX wieku, a jej korzenie sięgają ruchów związanych z dążeniami do równości rasowej i praw obywatelskich oraz realizacją ideologii „tygla". Koncepcja ta zakładała, że wszystkie grupy etniczne, narodowościowe, religijne mają jakieś pozytywne strony, a ich kultury zmieszane w tyglu połączą się $\mathrm{w}$ nową wyższą kulturę, co będzie stanowić źródło ich siły $\mathrm{i}$ integracji nowego narodu ${ }^{1}$. Zgodnie $\mathrm{z}$ wymienioną ideologią dopuszcza się jako naturalne nauczanie dwujęzyczne i wielokulturowość w edukacji. Podejmowane są, jak pisze T. Lewowicki:

rozmaite działania wspierające edukację wielokulturową, na przykład przygotowuje się dwujęzyczne programy nauczania, kształci nauczycieli posługujących się dwoma (albo kilkoma) językami².

Osiągnięto wiele, lecz działania na rzecz równości wszystkich obywateli nie przyniosły oczekiwanych rezultatów. Zamiast jedności, koncepcja wielokulturowości przynosiła niekiedy tendencje separatystyczne ${ }^{3}$. Idee wielokulturowości występowały głównie w USA, Kanadzie, Australii, ale również w krajach europejskich. Różne konteksty etniczne, narodowościowe, religijne, odmienna polityka rządowa, czy polityka społeczna przyczyniły się do zróżnicowanego obrazu wielokulturowości. Można zaobserwować tendencje zmian: od harmonijnego współżycia i kooperacji, aktywnej i świadomej tolerancji, poprzez życie obok, obojętność, formalną tolerancję w związku z granicami terytorialnymi, klasowymi i innymi, do wzajemnych niechęci, odrzucenia, marginalizacji i otwartych konfliktów.

${ }^{1}$ M. Krug, The Melting of the Ethnics, Bloomington 1976, s. 12.

${ }^{2}$ T. Lewowicki i in. (red.), Edukacja wobec tadu globalnego, Warszawa 2002, s. 21-22.

${ }^{3}$ J. Ambrosewicz-Jacobs, Tolerancja. Jak uczyć siebie i innych, Kraków 2004, s. 71. 
W Europie pomijano mniejszości religijne, wyznaniowe, etniczne, czy językowe, a głównie koncentrowano się na nowych emigrantach. Koncepcja wielokulturowości, realizowana od lat 70. XX wieku, zapewniała edukację falom napływowym $\mathrm{z}$ byłych kolonii i gastarbeiterom $\mathrm{z}$ państw słabo rozwiniętych. Edukacja była głównie zorientowana na działania adaptacyjne i przewidywała powrót ludności napływowej do kraju pochodzenia. Dopiero niedawno zdano sobie sprawę, jak pisze J. Nikitorowicz:

(...) że ludność napływowa pozostając, tworzy na stałe społeczeństwa wielokulturowe z wieloma problemami, gdyż demokracja akceptując pluralizm i umożliwiając realizację potrzeb różnych grup ludności, nie stworzy warunków, w których różnorodność kulturowa mogłaby być realizowana ${ }^{4}$.

Ponadto, należy zwrócić uwagę, że w większości społeczeństw doszły oczekiwania różnych grup mniejszościowych zamieszkujących od wieków na swoich terytoriach, które zaczęły upominać się o swoje prawa i możliwość zachowania własnego dziedzictwa kulturowego. Według badaczy problematyki wielokulturowości istnieją przesłanki, że społeczeństwa będą coraz bardziej wielokulturowe. Ostatnie dekady ubiegłego wieku stały się czasem krystalizacji nowego spojrzenia na sprawy edukacji w społeczeństwach wielokulturowych. Różne jej odmiany próbuje się zastąpić edukacją międzykulturową ${ }^{5}$. Dlatego podejmowane są próby określenia pojęcia wielokulturowego społeczeństwa i edukacji wielokulturowej. Według Rady Europy i Komisji Europejskiej: w społeczeństwie, w którym różne kultury, grupy narodowościowe i inne grupy wspólistniejące obok siebie nie nawiązują ze sobą konstruktywnych i prawnych kontaktów postrzegane są jako zagrożenie. Mogą na tym tle rodzić się uprzedzenia, rasizm i inne formy dyskryminacji ${ }^{6}$. Edukacja wielokulturowa wyrosła z różnych potrzeb i doświadczeń, i ma rozmaite wersje oraz odczytania społeczne. Jedną z najbardziej charakterystycznych cech tej edukacji jest "bycie obok siebie" grup ludzi i ich kultur. To „bycie obok siebie” według T. Lewowickiego:

odbywało się zazwyczaj i odbywa w warunkach asymetrii, nierówności szans rozwojowych, możliwości wzajemnego oddziaływania. Grupy dominujące (elity władzy) wyznaczały zakres swobód dla grup mniejszościowych. Bardziej lub mniej ukrytym celem poczynań edukacyjnych była asymilacja lub utrzymanie spokoju spolecznego ${ }^{7}$.

${ }^{4}$ J. Nikitorowicz, Edukacja regionalna i międzykulturowa, Warszawa 2009, s. 264-265.

${ }^{5}$ T. Lewowicki i in. (red.), Edukacja wobec tadu globalnego, s. 26.

${ }^{6}$ Rada Europy i Komisja Europejska, Uczenie się międzykulturowe, Strasburg 2000 (wyd. polskie: Fundacja Rozwoju Systemu Edukacji, Warszawa, s. 98).

7 T. Lewowicki i in. (red.), Edukacja wobec tadu globalnego, s. 25. 
Edukacja wielokulturowa to model działań edukacyjny,

uwzględniający potrzeby rożnych grup kulturowych zamieszkujących w określonym środowisku, motywujących ich do aktywnego uczestnictwa. Szczególnie zwraca się uwagę na rolę szkoły, która powinna wypracować programy nauczania i wychowania wielokulturowego, które odnosiłyby się do poszanowania zróżnicowania etnicznego i kulturowego ${ }^{8}$.

Dyrektywa Komisji Europejskiej z 1988 roku podkreśla konieczność podjęcia we wspólnocie takich działań, aby pomóc uczniom w kształtowaniu spojrzenia na Europę, jak na społeczność wielokulturową i wielojęzyczną. Wspieranie podobnych założeń ma obecnie postać finansowania przez Unię Europejską inicjatyw międzynarodowych, międzykulturowych, i innych, realizowanych przez krajowe jednostki samorządowe różnych szczebli oraz organizacje pozarządowe, $\mathrm{w}$ tym stowarzyszenia romskie.

Polskie doświadczenia $\mathrm{w}$ nauczaniu wielokulturowym mogły pojawić się dopiero po przeobrażeniach ustrojowych roku 1989. Wcześniej prowadzono politykę jednolitości narodowej, a kwestię różnic narodowościowych i etnicznych przemilczano lub dążono do ich likwidacji. Przeobrażenia demokratyczne spowodowały orientacje polskiego społeczeństwa na współpracę z krajami Europy Zachodniej, a integracja ze strukturami europejskimi zaowocowała aprobatą dla przyjętej tam wcześniej polityki edukacyjnej Unii Europejskiej ${ }^{9}$. Sytuacja w Polsce pod względem zachowania wielokulturowości jest niewątpliwie trudna, ponieważ istnieją głęboko zakorzenione uwarunkowania historyczne i religijne, odwołujące się często do uprzedzeń i stereotypów. Wobec tego w planach kształcenia wielokulturowego proponuje się odnajdywanie elementów łączących ze sobą poszczególne grupy narodowe i mniejszości. Jak prognozuje J. Nikitorowicz, który zajmuje się problematyką wielokulturowości, w bliskiej przyszłości systemy edukacyjne $\mathrm{w}$ państwach europejskich z monokulturowych przekształcą się w multikulturowe i interkulturowe. Ma to związek z tym, że oprócz mniejszości etnicznych o statusie ukształtowanym historycznie, jak np. Romowie czy Serbowie Łużyccy, z powodu spodziewanych licznych migracji na terenie państw UE pojawią się przedstawiciele nowych ludów.

Zdaniem D. Wojakowskiego, zjawisko wielokulturowości wyznacza edukacji dwa rodzaje celów. Pierwszy obejmuje zagwarantowanie równouprawnienia określonej grupie etnicznej, przygotowanie do życia w danym społeczeństwie, przekazanie i kultywowanie języka oraz kultury własnej

${ }^{8}$ J. Nikitorowicz, Edukacja regionalna i międzykulturowa, s. 265.

${ }^{9}$ K. Karwowski, Jedność w różnorodności, Edukacja i Dialog, 2006, 177, s. 135. 
grupy. Drugi cel związany jest z aranżowaniem spotkań, zwłaszcza kultury dominującej z grupami mniejszości etnicznej ${ }^{10}$. Zatem

zadania edukacji wielokulturowej wynikają z dostosowania szkolnictwa do zjawiska wielokulturowości, a zadania edukacji międzykulturowej polegają na wychowaniu do wielokulturowości, wyjściu jej naprzeciw ${ }^{11}$.

Edukacja międzykulturowa jest formą odpowiedzi, wyzwaniem wobec faktu istnienia wielokulturowości. Istotną cechą wymienionej edukacji stało się otwarcie na innych ludzi, grupy ,innych" i ich sprawy. Edukacja ta ma służyć wzajemnemu zbliżeniu i „byciu razem" - integracji.

\section{Edukacja międzykulturowa w zetknięciu z uchodźcami}

Zjawisko uchodźstwa znane jest ludzkości od tysięcy lat. Ciągle jednak wzbudza wiele emocji. Wynika to z faktu, iż decyzja o wejściu na "uchodźczą drogę" wymuszona jest przeważnie czynnikami zewnętrznymi, wiążącymi się zazwyczaj z cierpieniem, wojną, prześladowaniem, zagrożeniem życia. Termin „uchodźca” dla wielu ludzi kojarzy się z człowiekiem, który ma za sobą traumatyczne przejścia. Polska zapewnia uchodźcom ochronę zgodną z międzynarodowymi standardami dopiero od początku lat dziewięćdziesiątych ubiegłego wieku. Momentem przełomowym w polskiej polityce uchodźczej jest początek lat 90., bowiem 27 września 1991 roku Polska stała się stroną Konwencji Genewskiej z 1951 roku oraz Protokołu Nowojorskiego z 1967 roku i w związku z tym przyjęła międzynarodowe zobowiązania wobec ochrony osób poszukujących azylu. Konwencja Genewska precyzuje, kogo można uznać za uchodźcę, dzięki czemu we wszystkich państwach - sygnatariuszach obowiązuje to samo rozumienie tego pojęcia, zgodnie z którym za uchodźcę mogą być uznane osoby, które opuściły swój kraj na skutek uzasadnionej obawy przed prześladowaniem z powodu rasy, religii, narodowości, przynależności do określonej grupy społecznej lub przekonań politycznych ${ }^{12}$. Poszczególne strony Konwencji mogą również tworzyć własne, wewnętrzne akty prawne, które warunkują rodzaj i zakres świadczonej uchodźcom ochrony na terenie swojego państwa. Polskie ustawodawstwo zapewnia uchodźcom następujące formy ochrony prawnej: nadanie statusu uchodźcy, udzielenie ochrony uzupełniającej (od 2008 ro-

10 J. Nikitorowicz, Edukacja regionalna i międzykulturowa, s. 322.

${ }_{11}$ D. Wojakowski, Wielokulturowość pogranicza, Kraków 2002, s. 124.

12 Konwencja dotycząca statusu uchodźców, sporządzona w Genewie 28 lipca 1951 r., art. 1. 
ku), zgody na pobyt tolerowany (od 2003 roku), azylu oraz ochrony wczasowej. W praktyce stosuje się głównie ochronę uzupełniającą oraz status uchodźcy. Status uchodźcy przyznawany jest osobom, które spełniają kryteria zamieszczone $\mathrm{w}$ Konwencji, zaś ochrona uzupełniająca udzielana jest cudzoziemcom, którzy nie spełniają wymogów do nadania statusu uchodźcy, ale którym po powrocie do kraju pochodzenia zagrażałoby poważne niebezpieczeństwo, np. skazanie na karę śmierci, tortury, nieludzkie traktowanie, poważne zagrożenie zdrowia lub życia wynikające z powszechnego stosowania przemocy wobec ludzkości cywilnej w sytuacji konfliktu zbrojnego ${ }^{13}$.

Integracja uchodźców ze społeczeństwem goszczącym uznawana jest za stan najbardziej pożądany. Jednakże brak jednoznacznych wytycznych, które pozwoliłyby określić, na czym miałby polegać proces ich integracji oraz wskaźników, na podstawie których można byłoby ocenić, czy zakończył się on sukcesem. Liczne definicje skupiają się na pewnych wymogach, które uchodźca powinien spełnić, aby można było uznać go za zintegrowanego, pomijając istotną rolę społeczności lokalnej w tym procesie ${ }^{14}$.

Jedno z nielicznych podejść akcentujących potrzebę współdziałania tych dwóch stron przedstawia definicja przyjęta przez UNHCR ${ }^{15}$, w której opisano integrację uchodźców jako:

dynamiczny, wielopłaszczyznowy proces dwustronny, wymagający wysiłku ze strony wszystkich zainteresowanych, w tym gotowości uchodźców do zaadaptowania się w społeczeństwie przyjmującym bez konieczności wyrzekania się własnej tożsamości kulturowej i takiej samej gotowości społeczności przyjmujących oraz instytucji publicznych do przyjęcia uchodźców i zaspokojenia potrzeb niejednorodnego społeczeństwa ${ }^{16}$.

Tak rozumiana integracja powinna dokonywać się zarówno w wymiarze prawnym, społeczno-ekonomicznym oraz kulturowym, a jej miernikiem będzie umiejętność samodzielnego funkcjonowania cudzoziemcy na teryto-

13 Ustawa o udzielaniu cudzoziemcom ochrony na terytorium Rzeczypospolitej Polskiej z 13.06. 2003 r., art. 3 i art. 15, DzU nr 128, poz. 1175.

${ }^{14} \mathrm{H}$. Grzymała-Moszczyńska, Uchodźcy - podręcznik dla osób pracujących z uchodźcami, Kraków 2000, s. 24.

${ }^{15}$ Wysoki Komisarz ONZ ds. Uchodźców (ang. The United Nations High Commissioner for Refugees - UNHCR) - stanowisko utworzone zgodnie z rezolucją nr 319 (IV) przyjętą przez Zgromadzenie Ogólne ONZ 3 grudnia 1949 r.; statut biura UNHCR został uchwalony rezolucją ZO ONZ nr 428 (V) z 14 grudnia 1950 r. Zadaniem UNHCR jest zapewnianie międzynarodowej ochrony uchodźcom i poszukiwanie trwałych rozwiązań problemu uchodźców $\mathrm{w}$ drodze dobrowolnej ich repatriacji lub asymilacji w nowych społecznościach narodowych.

${ }^{16}$ Komitet Wykonawczy UNHCR, Conclusion on Local Integration, 2005, nr 104. 
rium kraju przyjmującego oraz otwartość na wspieranie tego procesu przez społeczność goszczącą.

Zgodnie z polskim prawodawstwem, czas na integrację uchodźców następuje po otrzymaniu przez nich decyzji przyznającej którąś z form ochrony na terenie Rzeczypospolitej Polskiej i po opuszczeniu ośrodka dla uchodźców. W trudnym procesie integracji cudzoziemcy mogą liczyć na świadczoną pomoc społeczną na podstawie Indywidualnych Programów Integracji. Jest ona udzielana przez okres nie dłuższy niż 12 miesięcy i kierowana do cudzoziemców, którym przyznano status uchodźcy lub ochronę uzupełniającą i obejmuje:

- świadczenia pieniężne przeznaczone na utrzymanie (pokrycie kosztów zakupu żywności, odzieży, obuwia, środków higieny osobistej, opłat mieszkaniowych) oraz pokrycie wydatków związanych z nauką języka polskiego (która jest obligatoryjna);

- opłacanie składki na ubezpieczenie zdrowotne;

- pracę socjalną;

- poradnictwo specjalistyczne, $\mathrm{w}$ tym poradnictwo prawne, psychologiczne i rodzinne;

- udzielanie informacji oraz wsparcia w kontaktach $\mathrm{z}$ innymi instytucjami;

- inne działania wspierające proces integracji ${ }^{17}$.

W sytuacji, kiedy uchodźcy nie mogą wrócić do domu, najlepszym dla nich rozwiązaniem jest integracja $\mathrm{w}$ kraju, który udzielił im schronienia. Integracja ta opiera się na założeniu, że uchodźca może być pożytecznym członkiem społeczeństwa. Uchodźstwo to nieszczęście, które odebrało człowiekowi dom, materialny dorobek życia, ale nie jego wiedzę, umiejętności i doświadczenie. Poza sytuacjami wyjątkowymi uchodźcy chcą żyć jak inni, pracować, kształcić swoje dzieci i być „na swoim”. Ważne jest, aby wsparcie materialne potrzebne $\mathrm{w}$ pierwszym okresie po przybyciu do obcego kraju zmieniało swój charakter. Pomoc w integracji obejmuje: naukę języka kraju schronienia, poznanie obyczajów i kultury oraz zdobycie kwalifikacji zawodowych potrzebnych do podjęcia pracy. Działania te, niewątpliwie trudniejsze, czasem mniej wymierne niż wsparcie materialne, są niezwykle ważne, aby okres uzależnienia od pomocy był jak najkrótszy. Czas pobytu w ośrodku dla uchodźców jest niezbędny, ale przyzwyczaja do bezczynności i apatii.

Niezwykle istotnym elementem integracji jest edukacja dzieci uchodźców. Dla dzieci, które mają za sobą traumatyczne przeżycia regularne uczęszczanie do szkoły to jedna z najlepszych dróg powrotu do normalno-

17 Ustawa o pomocy społecznej z 12 marca 2004 r., art. 92, DzU nr 64, poz. 593. 
ści. Kontakt z rówieśnikami, błyskawiczna nauka języka, kiedy są rzucone na głęboką wodę powoduje, że to właśnie one najszybciej się integrują i stają przewodnikami dla swoich rodziców w nowym kraju. Doświadczenie uchodźców pokazuje, że pełna integracja możliwa jest dopiero $\mathrm{w}$ drugim pokoleniu, czyli obejmuje uchodźców, którzy trafili do obcego kraju jako dzieci lub się w nim urodzili18.

\section{Sytuacja dziecka - uchodźcy w polskiej szkole}

Proces integracji uchodźców w Polsce przebiega bardzo powoli, gdyż mają oni przed sobą wiele barier utrudniających adaptację. Problem uchodźstwa w polskiej szkole jest często mało znany, pomimo że z roku na rok rośnie w Polsce liczba cudzoziemców ubiegających się o status uchodźcy, którzy stają się elementem polskiego wielokulturowego społeczeństwa. Rodzi się więc potrzeba upowszechniania wiedzy na temat uchodźców i kształtowania postawy otwartości na ich potrzeby. Ważną rolę w kształtowaniu tej potrzeby powinna odgrywać szkoła, która za jeden z podstawowych celów stawia sobie formowanie $\mathrm{u}$ młodego człowieka postawy poszanowania tradycji i kultury własnego narodu, a także poszanowania innych kultur i tradycji. Jednocześnie, ma za zadanie podjąć odpowiednie działania w celu zapobiegania wszelkiej dyskryminacji i edukowania ku tolerancji i akceptacji osób reprezentujących inne rasy, religie i kultury ${ }^{19}$.

Polskie szkoły działające $\mathrm{w}$ środowisku wielokulturowym i stykające się na co dzień z problemem uchodźstwa mają przed sobą trudne zadanie. Dzieci uchodźców podlegają w Polsce obowiązkowi szkolnemu i mają prawo do bezpłatnej nauki. Często jednak wykazują niską frekwencję na zajęciach, zdarza się, że przerywają naukę. W szkole napotykają problemy związane $\mathrm{z}$ nieprzygotowaniem systemu szkolnego do edukacji dzieci cudzoziemców oraz niedostatecznym przygotowaniem nauczycieli. Dzieciom brakuje nawyku uczenia się i systematycznego przygotowywania się do lekcji, bo nie miały wcześniej gdzie się tego nauczyć. Dodatkowo występuje bariera językowa związana ze słabą znajomością lub nieznajomością języka polskiego, a w wielu przypadkach tylko znajomością języka ojczystego. W konsekwencji dzieci mają trudność w nauce, nie uczestniczą w zajęciach pozalekcyjnych oferowanych przez szkołę. $W$ wielu szkołach odmienności

${ }^{18}$ K. Koszewska, Zrozumieć innych, czyli jak uczyć o uchodźcach, Warszawa 2001, s. 10.

19 Podstawa programowa wychowania przedszkolnego i kształcenia ogólnego w poszczególnych typach szkół z 23 grudnia 2008 r., DzU nr 4, poz. 17. 
kulturowe pogłębione słabą znajomością języka powodują, że dzieci uchodźców izolowane są od grup rówieśniczych. Dołączyć można do tego częstą dyskryminację obcej kultury, a wraz z tym tworzenie atmosfery niesprzyjającej procesowi integracji. Dzieci uchodźców ubiegających się w Polsce o status uchodźcy pochodzą z reguły ze społeczności bardziej konserwatywnych, wyznających inną religię. Szkoła powinna starać się zaakceptować wszelkie różnice kulturowe, a szczególnie potrzeby swoich uczniów, wytyczając jednocześnie jasne granice, które powinni znać nauczyciele, uczniowie oraz rodzice ${ }^{20}$.

Co najmniej połowa z ogólnej liczby uchodźców to dzieci. Jest ich zatem około 25 milionów. Dzieci uchodźcy nie mają swojego kraju, dachu nad głową, czasem także rodziny. Osierocone lub porzucone, pozbawione poczucia bezpieczeństwa są dziećmi bez dzieciństwa ${ }^{21}$.

Polskie dzieci od najmłodszych lat powinny być przygotowywane do spotkania z uchodźcami, którzy jeśli okaże się im szacunek i zrozumienie, mogą mieć pozytywny wpływ na rozwój gospodarczy, ekonomiczny i kulturalny Polski. Rolę w przygotowaniu dzieci do spotkania z obcymi kulturowo uchodźcami pełni edukacja międzykulturowa. Edukacja ta ma uwrażliwić młodych ludzi, a zarazem uświadomić im, że pomimo różnic kulturowych, etnicznych, czy religijnych ludzie mogą żyć razem, mogą się ze sobą integrować, mogą współistnieć. W społeczeństwie międzykulturowym najważniejsza jest zasada "bycia razem”, a nigdy "bycia obok".

Celem edukacji międzykulturowej, jak już wcześniej wymieniono, jest rozumienie odmiennych kultur i umożliwienie dialogu pomiędzy nimi. To również dążenie do kształtowania u młodych ludzi postaw otwartości na uchodźców i rozwijanie umiejętności komunikacji z nimi, a także uczenie tolerancji i zrozumienia wobec "obcości", co odbywa się przede wszystkim na poziomie szkoły, ponieważ system edukacyjny jest odpowiedzialny za przygotowanie uczniów do życia w społeczeństwie wielokulturowym.

Polska szkoła XXI wieku powinna wychowywać młodych ludzi nie tylko ceniących i znających wartości własnego narodu, ale także, a może przede wszystkim, szanujących odrębność innych. To wychowanie młodego człowieka na samodzielnego, otwartego, pozbawionego kompleksów i rozumiejącego, że „inność” nie musi oznaczać „obcości”22. Dialog, dzięki któremu możliwe jest nawiązanie kontaktu z uchodźcą powinien zmierzać do „prze-

20 A. Kosowicz, Uchodźca, [w:] Uchodźca mój dobry sąsiad, red. P. Dziliński, Warszawa 2009, s. 49-50.

${ }^{21}$ M. Malczewska, Uchodźcy - broszura informacyjna, Poznań 2001, s. 26.

22 K. Stech, B. Ratuś, Pakty Praw Człowieka w procesie edukacji, Zielona Góra 1994, s. 12. 
łamania barier, lęków, uprzedzeń i stereotypów w duchu twórczego spotkania, a nie wrogości" 23 . Dialog taki ma miejsce wtedy, gdy istnieje wzajemnie uznana wolność, równouprawnienie, a także poszanowanie odmienności i odrębności oraz otwartość na drugiego człowieka. Otwartość gwarantuje relacje między ludźmi i prawo do odmienności, bo jak pisze B. SmolińskaTheiss: „Odmienność jest bogactwem każdej ze stron dialogu i zarazem wartością dodaną $w$ relacji" ${ }^{24}$. Spotkanie $z$ uchodźcą jest zawsze trudne, ale może być twórcze dla obu stron, ponieważ spotkanie z odmiennym, zderzenie z nieznanym stwarza szansę innej myśli.

\section{Praktyczny wymiar edukacji międzykulturowej w szkole podstawowej w powiecie bialskim}

W Szkole Podstawowej w Berezówce uczą się w jednej klasie dzieci pochodzenia polskiego i czeczeńskiego. Berezówka to mała wieś położona w powiecie bialskim, w gminie Zalesie w województwie lubelskim, licząca około 300 mieszkańców. Do szkoły tej uczęszczają dzieci z pobliskich wiosek oraz dzieci pochodzenia czeczeńskiego z ośrodka dla uchodźców w Horbowie, położonego w tej samej gminie. Szkoła Podstawowa w Berezówce liczy około 60 uczniów, co oznacza, że jest placówką bardzo małą w porównaniu $\mathrm{z}$ innymi szkołami funkcjonującymi na terenie gminy Zalesie.

Uczniowie w tzw. oddziale zintegrowanym są w wieku 5-6 lat. Niektóre dzieci uchodźców są w starszym wieku, jednak uczęszczają do klasy wraz $\mathrm{z}$ dziećmi pochodzenia polskiego, ponieważ mają braki $\mathrm{w}$ nauce, czasami znaczne: problemy $\mathrm{z}$ prostymi działaniami matematycznymi, problemy z czytaniem i pisaniem. W oddziale przedszkolnym w Szkole Podstawowej w Berezówce jest jedna nauczycielka - wychowawca, która ma bardzo trudne zadanie prowadzenia zajęć, gier, zabaw w dwujęzycznym oddziale. Przygotowywała się do pracy $\mathrm{w}$ oddziale przedszkolnym zróżnicowanym kulturowo, w którym są prowadzone zajęcia z edukacji polonistycznej dla dzieci uchodźców. Uczęszczają na nie wszystkie dzieci, ponieważ zainteresowanie wśród ich rodziców nauką języka polskiego jest bardzo duże. Dzieci uchodźców uczą się języka polskiego w różnym czasie, a wszystko zależy od ich ogólnego rozwoju i możliwości. Wychowawczyni w trakcie zajęć, jeśli jest taka potrzeba, poświęca więcej czasu dzieciom, które nie znają dobrze

${ }^{23}$ J. Nikitorowicz, Edukacja regionalna i międzykulturowa, s. 269.

${ }^{24}$ B. Smolińska-Theiss, Dzieciństwo - zmieniająca się kategoria społeczna, Problemy Opiekuńczo-Wychowawcze, 2002, 4, s. 5. 
języka polskiego. Oprócz języka polskiego nauczycielka posługuje się językiem rosyjskim, który dzieci czeczeńskie, nieznające języka polskiego, rozumieją $\mathrm{w}$ stopniu zapewniającym poprawną komunikację.

Z wywiadu przeprowadzonego z nauczycielem - wychowawcą wynika, że dzieci polskie i czeczeńskie w małym stopniu znają kulturę swoich kolegów. Na początku roku szkolnego przeprowadzone były przez nauczyciela zajęcia zapoznawcze $\mathrm{z}$ kolegami i koleżankami z innego kraju. $\mathrm{W}$ miarę możliwości nauczyciel stara się ułatwiać poznanie polskim uczniom kultury dzieci czeczeńskich, a jeśli zachodzi taka potrzeba mówi dzieciom polskim o kulturze narodu czeczeńskiego. Wynika z tego, że dzieci uchodźców nie są izolowane od dzieci pochodzenia polskiego. Odmienne kultury mogą mieć wpływ na kontakty koleżeńskie w grupie rówieśniczej i w niektórych przypadkach takie zjawiska się obserwuje. Kontakty koleżeńskie, relacje w oddziale są poprawne, z tym że nie zawsze dzieci uchodźców chcą uczestniczyć we wspólnych zabawach czy grach. Czasami można zaobserwować ich niechęć do podejmowania takich działań. Mimo tego, nauczyciel stara się zachęcać dzieci czeczeńskie do aktywnego udziału w życiu szkoły i współpracy z innymi uczniami.

Nauczyciele nie wypytują dzieci czeczeńskie o ich kulturę i tradycje, ponieważ zostali z nią zapoznani na początku roku szkolnego, jeszcze przed ich przybyciem do szkoły. Uważano, iż zbyt drobiazgowe wypytywanie może być źle odbierane przez dzieci, jak również przez ich rodziców. Należy jeszcze zaznaczyć, że $\mathrm{w}$ wymienionym oddziale przedszkolnym, jak również $\mathrm{w}$ całej szkole, nie występują problemy związane z dyskryminacją uczniów innego pochodzenia. Dzieci polskie integrują się samodzielnie z dziećmi czeczeńskimi, tylko w niektórych sytuacjach potrzebują pomocy nauczyciela. Komunikują się ze sobą i uczestniczą we wspólnych grach czy pracach, nawiązując więzi koleżeńskie. Taki sposób integrowania „krok po kroku" buduje pozytywne relacje pomiędzy dziećmi.

\section{Podsumowanie}

Wydawać by się mogło, że mała miejscowość jaką jest Berezówka w powiecie bialskim nie poradzi sobie z przyjęciem uchodźców. Jednak obserwuje się, iż stosunki między nauczycielami polskimi a dziećmi czeczeńskimi i ich rodzicami są poprawne, takie jak między dziećmi polskimi. Dalsze prowadzenie badań dotyczących funkcjonowania w społeczeństwie wiejskim uchodźców jest niezbędne i zaplanowane przez autorkę. Na podstawie już przeprowadzonych badań można stwierdzić, że w przyszłości re- 
lacje między uchodźcami a Polakami na wsi będą rozwijać się w sposób właściwy.

Zarysowany $\mathrm{w}$ artykule praktyczny wymiar edukacji międzykulturowej stwarza możliwości wychowania młodego pokolenia do takich wartości, jak: tolerancja, szacunek do innych kultur i narodowości, nastawienie na dialog społeczny, samodzielne zdobywanie wiedzy i jej kreatywne wykorzystywanie, zdolność widzenia własnych działań w szerszej perspektywie. Edukacja wielokulturowa przeciwdziała takim zjawiskom społecznym, jak: rasizm, przesąd i dyskryminacja. Aby te cele osiągać, powstaje jednak konieczność przygotowania zmian w funkcjonowaniu szkolnictwa, które obejmą nie tylko obecny stan zróżnicowania etnicznego, ale określą zakres, formy i zasady wprowadzania edukacji międzykulturowej. Na poziomie szkoły należy zacząć od pozytywnego nastawienia zachowania uczniów i nauczycieli, oczekiwań wobec uczniów, ich rodzin oraz społeczności lokalnych.

\section{BIBLIOGRAFIA}

Ambrosewicz-Jacobs J., Tolerancja. Jak uczyć siebie i innych, Kraków, Stowarzyszenie Willa Decjusza 2004.

Grzymała-Moszczyńska H., Uchodźcy - podręcznik dla osób pracujacych z uchodźcami, Kraków 2000.

Karwowski K., Jedność w różnorodności, Edukacja i Dialog, 2006, 177.

Komitet Wykonawczy UNHCR, Conclusion on Local Integration, 2005, 104.

Konwencja dotycząca statusu uchodźców, sporządzona w Genewie 28.07.1951 r., art. 1.

Kosowicz A., Uchodźca, [w:] Uchodźca mój dobry sąsiad, red. P. Dziliński, Warszawa 2009.

Koszewska K., Zrozumieć innych, czyli jak uczyć o uchodźcach, Wydawnictwo CODN, Warszawa 2001.

Krug M., The Melting of the Ethnics, Bloomington 1976.

Lewowicki T., Nikitorowicz J., Pilch T., Tomiuk S. (red.), Edukacja wobec ładu globalnego, Wydawnictwo Akademickie Żak, Warszawa 2002.

Malczewska M., Uchodźcy - broszura informacyjna, Poznań 2001.

Nikitorowicz J., Edukacja regionalna i międzykulturowa, Wydawnictwa Akademickie i Profesjonalne, Warszawa 2009.

Podstawa programowa wychowania przedszkolnego i kształcenia ogólnego w poszczególnych typach szkół z 23 grudnia 2008 r., DzU nr 4, poz. 17.

Smolińska-Theiss B., Dzieciństwo - zmieniajaca się kategoria społeczna, Problemy Opiekuńczo-Wychowawcze, 2002, 4.

Stech K., Ratuś B., Pakty Praw Człowieka w procesie edukacji, Zielona Góra 1994.

Ustawa o pomocy społecznej z 12 marca 2004 r., art. 92, DzU nr 64, poz. 593.

Ustawa o udzielaniu cudzoziemcom ochrony na terytorium Rzeczypospolitej Polskiej z 13.06.2003 r., art. 3 i art. 15, DzU nr 128, poz. 117.

Wojakowski D., Wielokulturowość pogranicza, Zakład Wydawniczy Nomos, Kraków 2002. 